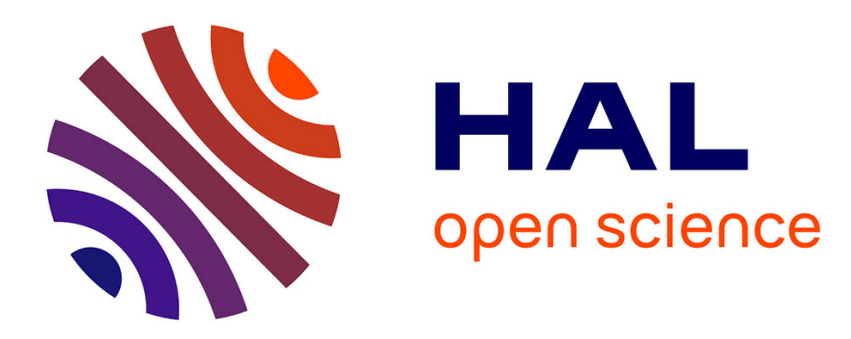

\title{
A study of cross slip activation parameters in copper
}

J. Bonneville

\section{To cite this version:}

J. Bonneville. A study of cross slip activation parameters in copper. Revue de Physique Appliquée, 1988, 23 (4), pp.677-677. 10.1051/rphysap:01988002304067700 . jpa-00245826

\section{HAL Id: jpa-00245826 https://hal.science/jpa-00245826}

Submitted on 1 Jan 1988

HAL is a multi-disciplinary open access archive for the deposit and dissemination of scientific research documents, whether they are published or not. The documents may come from teaching and research institutions in France or abroad, or from public or private research centers.
L'archive ouverte pluridisciplinaire HAL, est destinée au dépôt et à la diffusion de documents scientifiques de niveau recherche, publiés ou non, émanant des établissements d'enseignement et de recherche français ou étrangers, des laboratoires publics ou privés. 


\section{A STUDY OF CROSS SLIP ACTIVATION PARAMETERS IN COPPER}

J. Bonneville

EPF Lausanne, Institut Génie Atomique 1015 - Lausanne (Suisse)

An important factor for the stability of a dislocation line in a glide plane is its eventual dissociation or core spreading in this plane. Thus, due to energetical reasons, a dislocation has a tendency to lie in the plane where its dissociation width is largest. However, this plane is not necessarily the most favoured slip plane in terms of the local stresses. In order to glide, the dislocation can escape from its initial slip plane. This process of cross slip is achieved by surmonting an energy barrier. From linear elasticity, Escaig [1] has established that in the f.c.c. structure the driving force for cross slip is the component of the shear stress acting on the two opposite edge characters of the Shockley partials. More precisely, cross slip is mainly dependent on the ratio of effective dissociation widths on the primary and the cross slip planes. However, this model has never been fully tested, since in order to determine the activation parameters of a thermally activated process, it is necessary to create conditions in which a large number of individual events are simultaneously activated. For instance, it has been recently shown [2] that the usual $\tau_{\text {III method }}$ does not allow these measurements since at this stage of deformation cross slip events occur together with other forest processes.

A few years ago, a new experiment succeeded in producing a burst of cross slip at yielding [3]. This experimental procedure (fig. 1) is as follows: i) first, a large single crystal is predeformed in compression along a multislip [110] orientation up to the end of stage II. ii) Second, samples are extracted from this predeformed block and deformed again. The new deformation axis is taken in such a way that the primary plane was not previously stressed. Under these conditions, yielding occurs when the new slip dislocations, which are severely constrained by the predeformation forests, can escape by cross slip. This technique has been used to measure the activation volume and activation

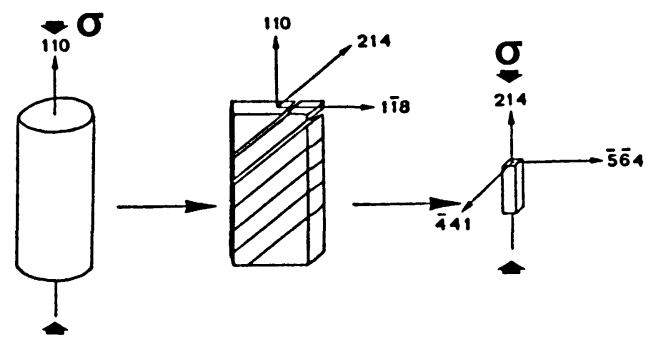

Figure 1.

energy of the cross slip mechanism in pure copper at temperatures between $150 \mathrm{~K}$ and $473 \mathrm{~K}$. For example, in fig. 2 are presented a typical stress-strain curve and the strain dependence of the true activation volume. These results have been obtained at room temperature for a strain rate of about $6 \times 10^{-5} \mathrm{~s}^{-1}$. It is clear from the non monotonic variation of the activation volume that two differents processes are involved. At the macro elastic limit the activation volume has a minimum value which correspond to the activation volume for cross-slip. After yielding, the activation volume increases to a rather high value which can be attributed to a forest cutting process. The experimental results obtained at the macro elastic limit for several other temperatures are summarized in [4].

Between 250K and 400K, we have obtained a large decrease of the yield stress and an activation volume almost constant around a value of $350 \mathrm{v}$, where $v=b^{3} \sqrt{3} / 2$, in good agreement with the theoretical prediction of the Escaig's model. This corresponds to a dissociation width of $16 \pm 2 \AA$ for a screw dislocation. Moreover, we have estimated the activation energy $\Delta \mathrm{Go}=1,15 \pm 0,37$ $\mathrm{eV}$, which is between the two theoretical values given by the model, depending on whether that cross slip should occured with one or two constrictions. Thus, these experimental results clearly confirm the validity of the model. Below $250 \mathrm{~K}$, and above $400 \mathrm{~K}$, the yield stress is temperature independent and the activation volume has a distinctly higher value $(>1000 \mathrm{v})$. For these conditions, there is experimental evidence that the predeformation substructure is not stable with respect to temperature or stress, and the burst of cross slip is screened by other processes.

Finally, transmission electron microscopy observations, using both conventional and in situ deformation methods, have been performed in order to examine the evolution of the dislocation substructure at different stages of deformation.

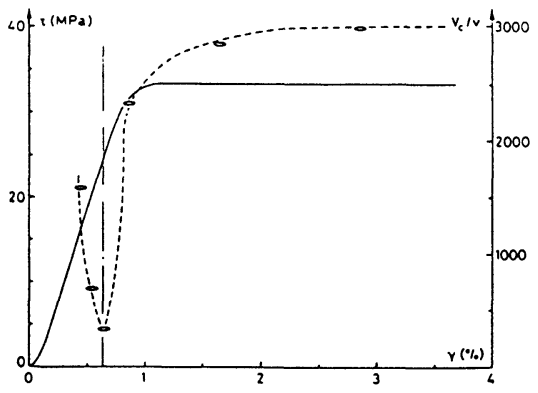

Figure 2.

References :

[1] B. Escaig, J. Phys. 29 (1968) 225.

2] J. Bonneville, Thèse de Doctorat no 607 , Lausanne (1985).

[3] J. Bonneville et B. Escaig, Acta Met. 27 (1979 1477 .

[4] J. Bonneville, D. Caillard, M. Carrard and J.L. Martin : this conference. 